\section{JUST THE FACTS \\ On Retirement Issues}

February 2003, Number 6
CENTER FOR

RETIREMENT

R E S E A R C H

AT BOSTON COLLEGE

\title{
The Declining Role of Social Security
}

\section{By Alicia H. Munnell*}

\section{Introduction}

Policymakers have focused considerable attention on alternative ways of eliminating Social Security's 75-year financing gap, but lost in the debate is the fact that even under current law Social Security will provide less retirement income relative to previous earnings than it does today. Combine the already legislated reductions with potential cuts due to closing the financing gap, and Social Security may no longer be the mainstay of the retirement system for many people. Recognizing the declining role of Social Security is important because future retirees will need to find alternative income sources as they age.

Today, the frequently quoted replacement rate for the "medium earner" who retires at age 65 is 41 percent; that is, Social Security benefits are equal to 41 percent of the individual's previous earnings. ${ }^{1}$ Under current law, three factors will reduce this replacement rate: 1 ) the extension of the normal retirement age; 2) the increase in Medicare Part B premiums; and 3) the taxation of Social Security benefits. The following section considers the impact of each of these developments.

\section{The Impact of the Increase in the Normal Retirement Age}

First, under current law, the Normal Retirement Age is scheduled to increase from 65 for those reaching 62 in 2000 to 67 for people reaching age 62 in 2022. The increase in the Normal Retirement Age is equivalent to an across-theboard benefit cut. For those who continue to retire at age 65, this cut takes the form of lower monthly benefits; for those who extend their worklives, it takes the form of fewer years of benefits. Thus, as reported in the Social Security Trustees Report, the replacement rate for the medium earner will drop from 41 percent to 36 percent for people who retire at age 65 in 2030 (Table 1). ${ }^{2}$ Table 1 also shows the replacement rates for low and maximum earners.

Table 1: Social Security Replacement Rates at Age 65 under Current LaW

\begin{tabular}{cccc}
\hline YEAR & $\begin{array}{l}\text { LOW } \\
\text { EARNER }\end{array}$ & $\begin{array}{l}\text { MEDIUM } \\
\text { EARNER }\end{array}$ & $\begin{array}{l}\text { MAXIMUM } \\
\text { EARNER }\end{array}$ \\
\hline 2000 & 55.5 & 41.2 & 27.3 \\
2030 & 49.1 & 36.5 & 24.0 \\
\hline
\end{tabular}

Source: Social Security Administration, $2002 b$.

\footnotetext{
* Alicia H. Munnell is the Director of the Center for Retirement Research at Boston College (CRR) and the Peter F. Drucker Professor of Management Sciences at Boston College's Carroll School of Management.
}

${ }^{1}$ The Social Security Administration (SSA) used to report benefits for low, average, and high earners as a percent of earnings in the last year prior to retirement. Starting with the 2002 Trustees Report, SSA gives figures for low, medium, and high earners as a percent of career-averaged, wage-indexed earnings. The medium earner is assumed to earn about the level of the national average wage in each year.

${ }^{2} 2000$ is used as the base year to show the status quo before the impact of the gradual increase in the normal retirement age. 


\section{Deducting Medicare Part B Premiums}

The second development that will affect future replacement rates is the rising cost of Medicare. Premiums for Medicare Part B, which are automatically deducted from Social Security benefits, are scheduled to increase from 6 percent of benefits for someone retiring today to 9 percent for someone retiring in 2030 (Table 2). Moreover, since premiums are scheduled to rise rapidly after retirement, they will account for an even larger share of Social Security benefits as recipients age, potentially consuming all the cost-ofliving adjustments provided along the way.

Table 2: Medicare Premiums as a Percent of Social Security Benefits

\begin{tabular}{cccc}
\hline YEAR & AT AGE 65 & YEAR & $\begin{array}{c}\text { SAME PERSON AT } \\
\text { AGE } 85\end{array}$ \\
\hline 2000 & 6.0 & 2020 & 10.6 \\
2030 & 9.1 & 2050 & 13.6 \\
\hline
\end{tabular}

Source: Social Security Administration, 2002a.

\section{Taxing Sociall Security Benefits}

The third factor that will reduce Social Security benefits is the extent to which they are taxed under the personal income tax. Under current law, individuals with less than $\$ 25,000$ and married couples with less than $\$ 32,000$ of "combined income" do not have to pay taxes on their Social Security benefits. (Combined income is adjusted gross income as reported on tax forms plus nontaxable interest income plus one half of Social Security benefits.) Above those thresholds, recipients must pay taxes on either 50 or 85 percent of their benefits (Table 3).
Table 3: Percent of Social Security Benefits Subject to Personal Income Taxation

\begin{tabular}{llc}
\hline $\begin{array}{l}\text { FAMILY }_{\text {TYPE }} \\
\text { Individual }\end{array}$ & $\begin{array}{l}\text { "CombINED INCOME" } \\
\text { LIMITS }\end{array}$ & PerCENT \\
& Less than $\$ 25,000$ & 0 \\
& $\$ 25,000-\$ 34,000$ & 50 \\
& Above $\$ 34,000$ & 85 \\
\hline Couple & Less than $\$ 32,000$ & 0 \\
& $\$ 32,000-\$ 44,000$ & 50 \\
& Above $\$ 44,000$ & 85 \\
\hline
\end{tabular}

Source: Committee on Ways and Means, U.S. House of Representatives, 2000.

Today, only about 20 percent of people who get Social Security have to pay taxes on their benefits, so the beneficiary with a history of medium earnings - and thus about $\$ 14,000$ of Social Security benefits - probably does not pay any taxes. But the thresholds are not indexed for growth in average wages or even for inflation, so in the future a significantly higher percentage of recipients will be subject to tax. By 2030, the Social Security benefit for the worker with a history of medium earnings will nearly triple to about $\$ 38,000$. If other income increases similarly, many medium earners will pay tax on half of their benefits. (Note that the full Social Security benefit is considered for tax purposes, even though the Medicare Part B premium is deducted before payment.) A 15 percent personal income tax on half of the benefits will reduce replacement rates by another 7.5 percent compared to today. ${ }^{3}$

\footnotetext{
${ }^{3}$ Replacement rates are typically expressed on a pre-tax basis, i.e. pre-tax benefits as a percent of pre-tax earnings. Subtracting taxes from benefits in the current exercise means that the resulting ratio will consist of post-tax benefits relative to pre-tax earnings. While it would be technically possible to produce this ratio on a
}

consistent post-tax basis, this brief relies on the commonly-reported pre-tax replacement rate as the benchmark. Also, using a full post-tax measure would not affect the main point - that taxation of Social Security benefits will significantly reduce replacement rates in the future. 


\section{Closing the Financing Gap}

The final development, unlike those discussed above, is by necessity speculative. That is, how much of the current 75-year financing shortfall will be eliminated by putting more money into the system as opposed to cutting benefits? Eliminating the entire 75 -year deficit by reducing benefits alone would require a 13 percent cut in benefits right now. But that figure makes no allowance for protecting the benefits of those 55 and over and the benefits for the disabled.

Holding these groups harmless requires a benefit cut of about 20 percent to restore balance. Assume that the final solution involved splitting the difference so that benefits were cut 10 percent and the rest of the gap was eliminated through additional revenue. This would reduce benefits by an additional 10 percent.

\section{Combined Impact}

Table 4 summarizes, for the average worker retiring at age 65 , the combined impact on the replacement rate of raising the Normal Retirement Age from 65 to 67, the rapidly rising Medicare premiums, the eventual taxation of a portion of Social Security benefits, and the possible benefit reductions associated with restoring balance to the program. These

Table 4: Social Security Replacement Rate IN 2030 for a Medium Worker

\begin{tabular}{lcc}
\hline DEVELOPMENT & \multicolumn{2}{c}{ REPLACEMENT RATE IN 2030} \\
& AGE 65 & AGE 62 \\
\hline Unadjusted & 41.2 & 33.0 \\
$\begin{array}{l}\text { After Extension of Normal } \\
\text { Retirement Age }\end{array}$ & 36.5 & 29.2 \\
$\begin{array}{l}\text { After Medicare Part B } \\
\text { Premium }\end{array}$ & 33.2 & $25.9 *$ \\
$\begin{array}{l}\text { After Personal Income Tax } \\
\text { After 10\% Benefit Cut to }\end{array}$ & 30.5 & 23.7 \\
Eliminate Financing Gap & 26.9 & 20.8 \\
\hline
\end{tabular}

Source: Tables 1-3 and author's estimate.

*Note: For the individual retiring at age 62, the Medicare Part B premium will not begin until age 65. developments reduce the replacement rate from an unadjusted 41.2 percent to 26.9 percent by 2030. Table 4 also adds one more consideration - the potential for retiring before age 65 . If the worker retires at 62 as soon as benefits become available, the replacement rate would be reduced to 20.8 percent to make it actuarially equivalent with the age- 65 benefit. In short, forces already in place are likely to lead to a markedly reduced role for Social Security.

The virtually certain reduction in Social Security replacement rates will have a profound effect on the income of older Americans. As shown in Figure 1, for those 65 and older,

\section{Figure 1: Percent of Retirement Income by Source, for Those Age 65 and Older, 2000}
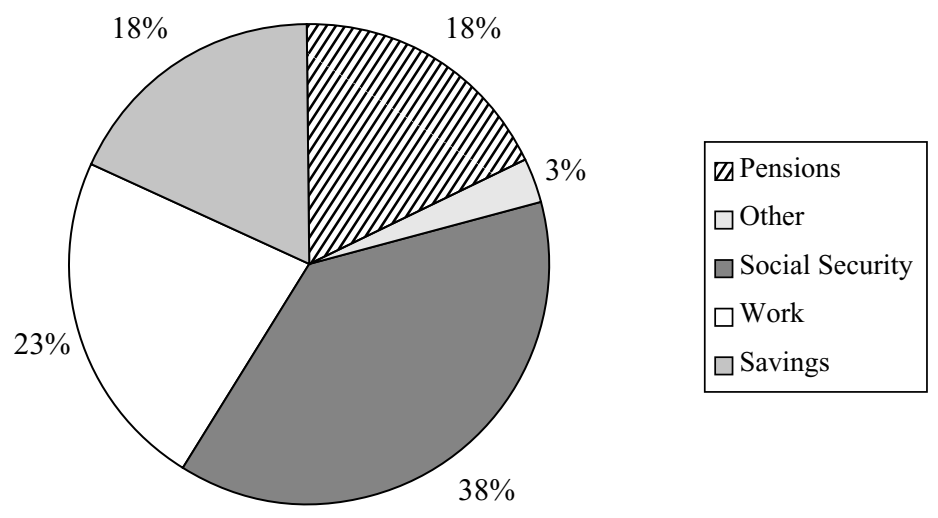

Source: Social Security Administration, $2002 c$.

Social Security currently accounts for 38 percent of total resources. Of course, Social Security represents an even larger share at older ages since earnings tend to diminish in importance. As Social Security replacement rates decline, some other sources of income must rise to take its place for people to avoid a sharp drop in consumption in retirement. More private pension income is one option, but only half the workforce is covered by a pension at any moment in time. Additional private saving is another possibility, but efforts to increase individual savings have been remarkably unsuccessful. Some have advocated another layer of government-sponsored retirement accounts to supplement Social Security, and this might be a useful effort to pursue. 
One avenue that has received little attention but that has a potentially significant payoff is for people to work longer. While working longer means less leisure time, it is a powerful antidote to reductions in other retirement income sources. Working directly increases a person's current income; it avoids the actuarial reduction in Social Security benefits; it allows people to contribute more to their 401(k) plans; and it postpones the day when they start drawing down their pension accumulations or other retirement saving. Work has important non-monetary benefits as well; many people derive satisfaction from remaining productive and retaining social ties to their colleagues.

Regardless of how we as a nation decide to respond to the decline in Social Security replacement rates, it is clear that the composition of the income of older Americans will look very different in the future than it does today.

\section{References}

Committee on Ways and Means, U.S. House of Representatives. 2000. 2000 Green Book. Washington, DC: U.S. Government Printing Office.

Social Security Administration. 2002a. The 2002 Annual Report of the Board of Trustees of the Federal Hospital Insurance and Federal Supplementary Medical Insurance Trust Funds. Washington, DC: U.S. Government Printing Office.

Social Security Administration. 2002b. The 2002 Annual Report of the Board of Trustees of the Federal Old-Age and Survivors Insurance and the Disability Insurance Trust Funds. Washington, DC: U.S. Government Printing Office.

Social Security Administration. 2002c. Income of the Aged Chartbook 2000. Washington, DC: Social Security Administration.

\section{The Center for Retirement Research is proud to have CitiStreet as a corporate partner.}

(C) 2003, by Trustees of Boston College, Center for Retirement Research. All rights reserved. The research reported herein was supported by the Center's corporate partnership program. The opinions and conclusions expressed are solely those of the author and should not be construed as representing the opinions of the Center for Retirement Research at Boston College or the Center's corporate partners.

\section{Center for Retiritemient Research at Boston Colliege}

